Volodymyr Andrusevich, Ivan Obod

Kharkiv National University of Radio Electronics, Kharkiv, Ukraine

\title{
ASSESSMENT OF THE QUALITY OF INFORMATION SUPPORT BY AIR RADAR SURVEILLANCE SYSTEMS
}

\begin{abstract}
The paper pays attention to the consideration of the structure of user's information support of the airspace control system at the stage of primary information processing by the joined radar system. This system includes a primary and identification surveillance system, which allows considering the overall structure as a single synchronous network of surveillance information systems. Such a structure can be characterized by an overall integrated quality indicator of the information support of the airspace control system. Such a quality indicator can be the probability of information support, which is the product of the probabilities of correct detection of an air object by the primary radar and identification system on the basis of "friend-foe" and the probability of comparing the coordinate information of primary radar systems and identification systems. This approach allows changing the model of combining information for primary radar systems and identification systems so as to take into account the estimated coordinates of the air object by both information systems due to the weight combination of coordinates of air objects. The calculation of the coordinates of air objects according to the information of the primary radar systems and identification systems allows improving the quality of information support for decision makers in the air traffic control system.

Keywords: air traffic control system; primary and secondary radar surveillance systems; quality assessment of information support; integrated indicator of information processing quality Neumann-Pearson criterion.
\end{abstract}

\section{Introduction}

Problem statement and analysis of the literature. Primary $[1,2]$ and secondary (identification) $[3,4]$ radar surveillance systems (SS) are the basis for information support of the airspace control system. The first determines the spatial coordinates of the air object, and the second determines the state affiliation of the detected air object. These two radar systems form the basis of information support for decision-makers in the airspace control system. For this purpose, according to the information of the considered radar surveillance systems, the logbook of the air object is drawn up, which contains the coordinates of the detected air object and the sign "Own - alien".

Therefore, the form of air objects is formed by comparing the spatial coordinates calculated by the primary and secondary radar systems. The combination of information is carried out automatically and based on the comparison of the coordinates of air objects, calculated from the information of the primary radar systems and identification systems. Coordinates in the considered information systems are calculated on the basis of processing of a pack of the received signals by each radar system considered. When the coordinates of air objects, calculated according to the primary radar systems and identification systems, taking into account the resolutions of these surveillance systems, the affiliation "Own" is entered in the logbook of the air object. If there are no response signals on the identification system, the aerial object the affiliation "Alien" is entered to the logbook. At the same time, only the coordinates of the air object calculated according to the data of the primary radar system are entered to the logbook of the air object, regardless of what will be the sign of the air objects "Own or alien." This reduces the quality of these aerial objects with the "Own" sign, which is issued to decision makers. Indeed, the coordinates of air objects calculated from identification systems are more accurate and would improve the quality of information on the basis of "Own" air objects with a weight combination of information obtained by the radar surveillance systems under consideration. This would increase the likelihood of information being provided to decision makers in the airspace control system.

A sufficient number of scientific papers are devoted to the issue of combining information from joint radar surveillance systems. Thus, in [5], the combination of data for several sensors of surveillance systems in air traffic control is studied and it is shown that the creation of an excess of information allows improving the accuracy of tracking air objects and resistance to sensor errors.

[6-12] describes a set of algorithms combining primary radar information and identification system information. Pre-processing algorithms are described, which are used to remove false radar targets and preliminary processing of data of identification systems is given. Algorithms of combination of coordinates of air object are described, including alignment of coordinates of air objects obtained from various sensors, correlation between contacts, initiation of tracks, updating of tracks and processing of hypotheses of tracks. Various aspects of combination of information of considered information systems are considered and it is shown that during data merging it is possible to improve data quality due to weight combination of coordinate information of primary radar and identification systems and it is shown that accurate identification of air objects cannot be obtained when the identification system is used separately. The content of this article focuses on the algorithm for combining data from a network of radar surveillance systems, and the Bayesian network is considered as a merging algorithm.

The purpose of the work is to assess the quality of information support for consumers by surveillance radar systems for observing airspace with a combination of information from primary and identification radar systems. 


\section{Research results}

Structure of information pooling of surveillance radar systems. Let us consider the structure of information support of users at the stage of initial processing of information by combined radar system, which includes primary and identification systems of observation. The Air Object (AO) Logbook provided to decision makers should include: spatial coordinates of the AO; information on the identification of $\mathrm{AO}$ on the basis of "own-alien".

It should be noted that the leader is the primary SS, the coordinate information of which is embedded in the logbook of AO. The calculation of AO coordinate information by identification systems is required only for the combination of information of primary and interrogative SS, which significantly reduces the information capabilities of interrogative SS and, as a consequence, reduces the quality of information support to users.

Automatic calculation of AO coordinate information by compatible SS processing channels and formation of $\mathrm{AO}$ logbook is performed at the stage of primary information processing. Thus, the information processing structure includes a single signal detector, from the output of which a sequence of random zeros and ones is removed. The optimal signal detection threshold is selected, usually according to the NeumannPearson test. Thus, the detection of signals is carried out according to the required quality indicators, ie a fixed probability of false alarm $F_{0 i}$, and the probability of correct detection $D_{0 i}$. In this case, the signal is quantized at two levels (binary quantization), which allows a direct synthesis of algorithms and decision rules for processing digital binary-quantized signals.

The sequence of zeros and ones from the output of the signal detector of each information system is temporally sampled and then goes to the inputs of the detector and the AO coordinate meter. The task of the $\mathrm{AO}$ detector is to decide in an optimal way whether the received sample is a bundle of signals or it refers to the interference based on the analysis of the obtained sequence of zeros and ones.

To solve the formulated problem, the AO detector must process the incoming signals according to some algorithm. The algorithm for detecting AO is reduced to testing the hypothesis $H_{0}$ of the absence of $\mathrm{AO}$ against an alternative hypothesis $H_{1}$ of its existence, ie to form a plausibility relationship and compare this relationship with some predetermined number, which is chosen based on the allowable probability of false detection. The decision to detect $\mathrm{AO}$ with quality indicators $F_{1 i}$ and $D_{1 i}$ comes to the AO coordinate meter. Estimation of the coordinates of the instantaneous position of the AO is done simultaneously with the detection of the AO. The task of the AO coordinate meter is to optimally estimate the spatial coordinates of the AO based on the analysis of the obtained sequence of zeros and ones.

To solve the formulated problem, the AO coordinate meter must also process the incoming signals according to some algorithm. The optimal algorithm for measuring coordinates is synthesized, as a rule, by the criterion of maximum likelihood. The type of likelihood function depends on the statistical characteristics of the signals and interference, the shape of the antenna system pattern, as well as the method of scanning the SS antenna during the measurement process. Thus, when generating $\mathrm{AO}$ detection signals from the output of the AO coordinate meter of each channel of a compatible radar surveillance system, an estimate of the coordinate measurement vector $\hat{\vec{\alpha}}$ is issued, which is characterized by a correlation matrix of errors $\vec{C}^{-1}$ [11-13].

Based on the above, the information will be provided with partial indicators of the quality of information support will be the quality of the assessment of the coordinates of the observed air objects and the probability of correct detection of AO by each radar channel under consideration.

2. Evaluation of the quality of information combination of radar surveillance systems. Primary radar and identification systems of airspace control, as a rule, are placed on a single platform and carry out synchronous inspection of space. This allows to consider them as a common synchronous network of surveillance systems. Currently, to compile the logbook of the air object in each SS channel must be carried out [11]:

- detection and measurement of signal parameters (signal processing);

- detection and measurement of AO coordinates (primary information processing).

As shown in [12-14], an integral indicator of the quality of information support of the airspace control system can be the probability of information support, which, for the general case, can be written as follows

$$
P_{\text {inf }}=D_{P R} \cdot D_{I F F} \cdot P_{p o r},
$$

where $D_{P R}$ - the probability of correct detection of AO by the primary radar, $D_{I F F}$ - the probability of correct detection of AO by IFF system, $P_{\text {por }}$ - probability of comparison of coordinate information of primary radar systems and identification systems.

The probability of comparing the coordinate information of the primary radar systems and identification systems $P_{\text {por }}$ acts as the probability of combining the information of the considered information systems.

Further we will consider the issue of combining information without taking into account the information transmitted in the channel of identification systems.

The probability of correct detection of AO by each surveillance system $P_{i}=D_{1 i}(i=1,2) \quad P_{i}=D_{1 i}$, is a function

$$
D_{1 i}=f\left(D_{0 i}, F_{0 i}, P_{0}\right)=f\left(q_{0 i}, z_{0 i}, C_{i}, P_{0}\right),
$$

where $z_{0}(C)-$ analog (digital) signal detection threshold (AO), $q_{0 i}$ - signal-to-noise ratio in the information processing channel, $P_{0}$ - the relative capacity of the aircraft responder, which is characteristic 
of identification systems, $F_{0 i}=f\left(z_{0 i}\right)$ - probability of false alarm.

The relative bandwidth of the IFF aircraft response systems can be written as

$$
P_{0}=f\left(\lambda_{1}, \lambda_{2}, \lambda_{0}, t_{p}, k_{z}\right),
$$

where $\lambda_{1}$ - the intensity of the flow of request signals, which includes the flow of the considered requester, the flow of neighboring interrogators (intra-system interference) and the flow of correlated interference of the interested party; $\lambda_{2}$ - the intensity of the flow of request signals that cause the operation of the circuit suppression of the side lobes; $\lambda_{0}$ - the intensity of chaotic impulse interference in the request channel; $t_{p}$ - the time of paralysis of the aircraft responder when servicing the request signal; $k_{z}$ - the maximum load coefficient of the aircraft responder.

Due to the synchronicity of the primary radar systems and identification systems, it is possible to replace the processing at the level of detection and measurement of $\mathrm{AO}$ coordinates with a centralized one.

In this case, the structure of information processing must have in each channel a detector of individual signals, from the output of which is removed a sequence of random zeros and ones. The optimal detection threshold of these signals is selected according to the selected criterion.

Thus, the signal is detected by the required quality indicators, i.e. $F_{0 i}, D_{0 i}$.

Thus, when forming a decision on the detection of an air object from the output of the coordinate meter of the primary radar systems and identification systems, an estimate of the coordinate measurement vector $\hat{\vec{\alpha}}$ is issued, which is characterized by a correlation matrix of measurement accuracy $\hat{\vec{C}}^{-1}$.

In the information processing device, measurement estimates based on measurement vectors $\hat{\vec{\alpha}}_{p}$ and a correlation matrix of measurement accuracy $\hat{\vec{C}}_{p}^{-1}$ of each information system are combined, as a result of which the outgoing measurement vector and the correlation matrix of accuracy are calculated. In the future, the outgoing measurement vector $\hat{\vec{\alpha}}_{p}$ and the correlation accuracy matrix $\hat{\vec{C}}_{p}^{-1}$ are provided to the users.

The algorithm for combining information in the processing device is built, as a rule, so that the single marks of the channels of a compatible radar system are combined, if the azimuth angle between the centers of the packets does not exceed $\Delta \beta$, and the difference in their distances is $\Delta r$.

In this case, given that the deviations of the packet centers in the primary and secondary radars are independent and subject to normal distribution, the probability of combining information packets can be determined from the following ratio

$$
\begin{aligned}
P_{p o r} & =\frac{1}{4}\left[1+\Phi\left(\Delta \beta /\left(\sqrt{2} \sqrt{\sigma_{\beta 1}^{2}+\sigma_{\beta 2}^{2}}\right)\right)\right] \times \\
& \times\left[1+\Phi\left(\Delta r /\left(\sqrt{2} \sqrt{\sigma_{r 1}^{2}+\sigma_{r 2}^{2}}\right)\right)\right]
\end{aligned}
$$

where $\sigma_{\beta 1}, \sigma_{\beta 2}, \sigma_{r 1}, \sigma_{r 2}$ - root mean square deviations of azimuths (ranges) of primary radar packet centers and identification system.

3. Analysis of information support structure for information processing of surveillance radar systems. We estimate the probability of information support of consumers of the airspace control system for the considered model of combination of information of primary radar systems and identification systems as a function

$$
P_{\text {inf }}=f\left(k, q, P_{0}\right),
$$

where $k=q_{p} / q_{z}, q_{z}$ - signal-to-noise ratio in the channel of the identification system, $q_{p}$ - signal-tonoise ratio in the channel of primary radar systems, taking into account both the detection and measurement of AO coordinates.

Detection of the air object and measurement of its coordinates will be carried out on the basis of the analysis of all pack of the received signal data of primary radar systems and identification systems. The digital detection threshold of the air object was equal to half the packet of received signals. The results of the calculation are shown in Fig. 1,2. Calculations are obtained with the probability of false alarm detection of an air object that is $F=10^{-3}$. In this case, the continuous curve corresponds to the probability of information support for the existing model and method of combining information.

Other dependences are obtained for the proposed variant of combining information for different coefficients of readiness of the aircraft responder and signal-to-noise ratios in the information processing channels of primary radar systems and identification systems.

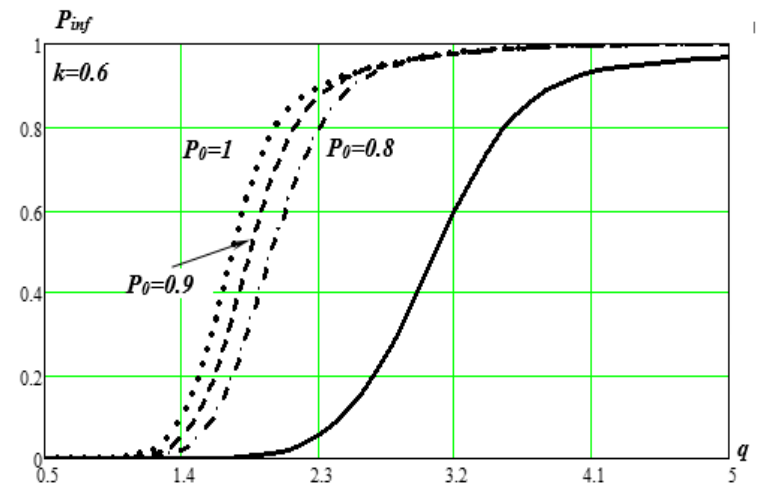

Fig. 1. Dependence $P_{\text {inf }}=f\left(k=0.6, q, P_{0}\right)$

The calculations of the probability of information support of decision makers in the airspace use control 
system presented in Fig. 1 show that for the signal-tonoise ratio of the primary radar and identification systems which is 0.6 while $q=2.3$ the probability of information support for the existing model is only 0,05 .

At that time, for the proposed model, the probability of information support is 0.8 for $P_{0}=0,8$; 0,88 for $P_{0}=0,9$ and 0,92 for $P_{0}=1$

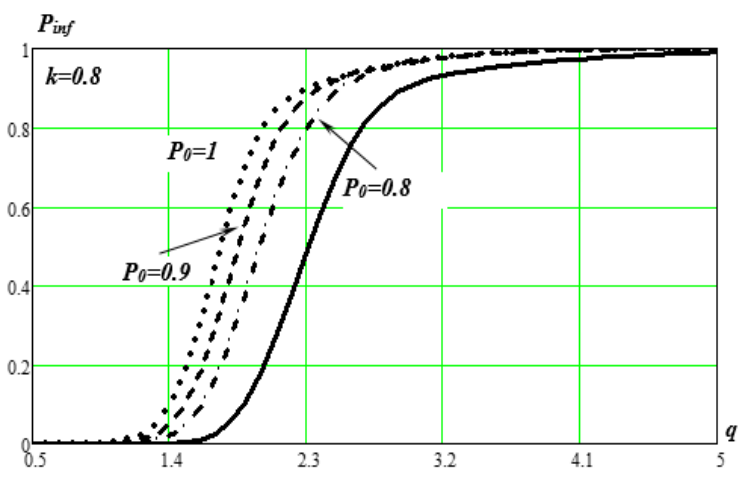

Fig. 2. Dependence $P_{\text {inf }}=f\left(k=0.8, q, P_{0}\right)$

The calculations of the probability of information support of decision makers in the airspace use control system presented in Fig. 2 show that the signal / noise ratio of the primary radar and identification systems is 0.8 , while $q=2.3$ the probability of information support for the existing model is only 0.45 .
At that time, for the proposed model, the probability of information support is also 0.8 for $P_{0}=0,8 ; 0,88$ for $P_{0}=0,9$ and 0,92 for $P_{0}=1$.

\section{Conclusions}

It is proved that changing the model of combining information of primary radar systems and identification systems which takes into account the estimated coordinates of the air object by the identification system due to the weight combination of coordinates of air objects calculated on the information of both primary radar systems and identification systems allows to improve quality.

Information services for decision-makers in the airspace use control system.

These calculations allow us to draw the following conclusions:

- the use of the proposed data processing of airspace surveillance systems, taking into account the possibility of using the equivalence of the fact of detection of an air object by the primary radar system and identification system is more appropriate than the existing model of information support of airspace use control system. information issued to the consumer;

- with the distributed processing of information of airspace surveillance systems decreases the impact of the coefficient of readiness of the aircraft respondent identification system quality of customer service.

\section{REFERENCES}

1. Bagad, V. S. (2009), Radar System, Technical Publications.

2. Bouwman. R. (2009), Fundamentals of Ground Radar for Air Traffic Control Engineers and Technicians, SciTech Publishing, Annotated edition. DOI: https://doi.org/10.1049/SBRA008E.

3. STANAG 4193 (2016), Document, Technical Characteristics Of IFF Mk X And Mk XII Interrogators And Transponders (Part V) - Technical Description Of The MkXII System, NATO Standard.

4. Malyarenko, A. S. (2007), Secondary radar systems for air traffic control and state radar identification [Sistemy vtorichnoy radiolokatsii dlya upravleniya vozdushnym dvizheniyem i gosudarstvennogo radiolokatsionnogo opoznavaniya], Handbook, Kharkiv : KhUPS, 78 p.

5. Liu, W., Wei, J., Liang, M., Cao, Y. and Hwang, I. (2013), "Multi-Sensor Fusion and Fault Detection using Hybrid Estimation for Air Traffic Surveillance", IEEE Transactions on Aerospace and Electronic Systems, vol. 49, no. 4, pp. 23232339. DOI: https://doi.org/10.1109/TAES.2013.6621819.

6. Carson, R. R., Meyer, M. P. and Peters, D. J. (1996), "Fusion of IFF and radar data", Proceeding of 1st Australian Data Fusion Symposium, Adelaide, SA, Australia, pp. 65-70. DOI: https://doi.org/10.1109/ADFS.1996.581083.

7. Carson, R. R. J., Meyer, M. P. and Peters, D. J. (1997), "Fusion of IFF and radar data", 16th DASC. AIAA/IEEE Digital Avionics Systems Conference. Reflections to the Future. Proceedings, Irvine, CA, USA, pp. 5.3-9. DOI: https://doi.org/10.1109/DASC.1997.635094.

8. Svyd, I., Obod, I., Maltsev, O., Tkachova, T. and Zavolodko, G. (2019), "Improving Noise Immunity in Identification Friend or Foe Systems", 2019 IEEE 2nd Ukraine Conference on Electrical and Computer Engineering (UKRCON), Lviv, Ukraine, pp. 73-77, DOI: https://doi.org/10.1109/UKRCON.2019.8879812.

9. Obod, I., Svyd, I., Maltsev, O. and Bakumenko, B. (2020), "Comparative Analysis of Noise Immunity Systems Identification Friend or Foe", 2020 IEEE 40th International Conference on Electronics and Nanotechnology (ELNANO), Kyiv, Ukraine, pp. 751-756. DOI: https://doi.org/10.1109/ELNANO50318.2020.9088856.

10. Schuck, T. M., Shoemaker, B. and Willey, J. (2000), "Identification friend-or-foe (IFF) sensor uncertainties, ambiguities, deception and their application to the multi-source fusion process", Proceedings of the IEEE 2000 National Aerospace and Electronics Conference. NAECON 2000. Engineering Tomorrow (Cat. No.00CH37093), Dayton, OH, USA, pp. 85-94. DOI: DOI: https://doi.org/10.1109/NAECON.2000.894896.

11. Komorniczak, W., Pietrasinski, J. and Solaiman, B. (2002), "Data fusion approach to threat assessment for radar resources management", SPIE 4731 Sensor Fusion: Architectures, Algorithms, and Applications VI. DOI: https://doi.org/10.1117/12.458384.

12. Strelnytskyi, O., Svyd, I., Obod, I., Maltsev, O., Voloshchuk, O. and Zavolodko, G. (2019), "Assessment Reliability of Data in the Identification Friend or Foe Systems", 2019 IEEE 39th International Conference on Electronics and Nanotechnology (ELNANO), Kyiv, Ukraine, pp. 728-731. DOI: https://doi.org/10.1109/ELNANO.2019.8783397. 
13. Svyd, I., Maltsev, O., Obod, I. and Zavolodko, G. (2020), "Fusion Method of Primary Surveillance Radar Data and ідентифікаційних системData", 2020 IEEE 11th International Conference on Dependable Systems, Services and Technologies (DESSERT), Kyiv, Ukraine, pp. 336-340. DOI: https://doi.org/10.1109/DESSERT50317.2020.9125040.

14. Obod, I. I., Strelnytskyi O. O., Andrusevich, V. A. (2015), Information network of airspace surveillance systems [Informatsiyna merezha system sposterezhedennya povitryanoho prostoru], Kharkiv : NURE, $271 \mathrm{p}$.

Received (Надійшла) 21.01.2021

Accepted for publication (Прийнята до друку) 12.05.2021

\section{ВідОМОсті ПРО АвтоРів / АвоUT THE AUTHORS}

Андрусевич Володимир Анатолійович - начальник управління інформаційних технологій та телекомунікаційних систем, Публічне акціонерне товариство «Південний гірничо-збагачувальний комбінат», Кривий Ріг, Україна;

Volodymyr Andrusevich - Head of the Department of Information Technologies and Telecommunication Systems, Southern Mining and Processing Plant Public Joint Stock Company, Kryvyi Rih, Ukraine, e-mail: volodymyr.andrusevytch@ gmail.com; ORCID ID: https://orcid.org/0000-0003-0095-3584.

Обод Іван Іванович - доктор технічних наук, професор, професор кафедри мікропроцесорних технологій і систем, Харківський національний університет радіоелектроніки, Харків, Україна;

Ivan Obod - Doctor of Technical Sciences, Professor, Professor of the Department of Microprocessor Technologies and Systems, Kharkiv National University of Radio Electronics, Kharkiv, Ukraine; e-mail: ivan.obod@nure.ua; ORCID ID: https://orcid.org/0000-0002-9898-0937.

\section{Оцінка якості інформаційного забезпечення радіолокаційними системами спостереження повітряного простору}

\section{В. А. Андрусевич, І. І. Обод}

Анотація. У роботі приділено увагу розгляду структури інформаційного забезпечення користувачів системи контролю повітряного простору на етапі первинної обробки інформації суміщеною радіолокаційною системою. Ця система включає первинну та ідентифікаційну системи спостереження, що дозволяє розглядати загальну структуру, як єдину синхронну мережу інформаційних систем спостереження. Така структура може характеризуватися загальним інтегральним показником якості інформаційного забезпечення системи контролю повітряного простору. Таким показником якості може бути імовірність інформаційного забезпечення, яка $\epsilon$ добутком імовірностей правильного виявлення повітряного об'єкту первинним радіолокатором і системою ідентифікації за ознакою «свій-чужий» та імовірності порівняння координатної інформації первинних радіолокаційних систем й ідентифікаційних систем. Такий підхід дозволяє змінити модель поєднання інформації первинних радіолокаційних систем та ідентифікаційних систем так, щоб враховувати оцінені координати повітряного об'єкта обома інформаційними системами за рахунок вагового поєднання координат повітряних об'єктів. Розрахунок координат повітряних об'єктів за інформацією первинних радіолокаційних систем та ідентифікаційних систем дозволяє підвищити якість інформаційного забезпечення осіб, які приймають рішення в системі контролю використання повітряного простору.

Ключові слова: система контролю повітряного простору; первинні та вторинні радіолокаційні системи спостереження; оцінка якості інформаційного забезпечення; інтегральний показник якості обробки інформації; критерій Неймана-Пірсона.

\section{Оценка качества информационного обеспечения радиолокационными системами наблюдения воздушного пространства}

\section{В. А. Андрусевич, И. И. Обод}

Аннотация. В работе уделено внимание рассмотрению структуры информационного обеспечения пользователей системы контроля воздушного пространства на этапе первичной обработки информации совмещенной радиолокационной системой. Эта система включает первичную и идентификационную системы наблюдения, позволяет рассматривать общую структуру, как единую синхронную сеть информационных систем наблюдения. Такая структура может характеризоваться общим интегральным показателем качества информационного обеспечения системы контроля воздушного пространства. Таким показателем качества может быть вероятность информационного обеспечения, которая является произведением вероятностей правильного обнаружения воздушного объекта первичным радиолокатором и системой идентификации по признаку «свойчужой» и вероятности сравнения координатной информации первичных радиолокационных систем и идентификационных систем. Такой подход позволяет изменить модель объединения информации первичных радиолокационных систем и идентификационных систем так, чтобы учитывать оценки координат воздушного объекта обеими информационными системами за счет весового сочетание координат воздушных объектов. Расчет координат воздушных объектов по информации первичных радиолокационных систем и идентификационных систем позволяет повысить качество информационного обеспечения лиц, принимающих решения в системе контроля использования воздушного пространства.

Ключевые слова: система контроля воздушного пространства; первичные и вторичные радиолокационные системы наблюдения; оценка качества информационного обеспечения; интегральный показатель качества обработки информации; критерий Неймана-Пирсона. 